\title{
Mutu gizi dan daya terima es krim indeks glikemik rendah berbahan polisakarida larut air umbi gembili (Dioscorea esculenta) dan tepung ubi jalar ungu (Ipomoea Batatas L. Poir)
}

Nutritional quality and acceptability of low glycemic index ice cream made from watersoluble polysaccharides gembili tubers (Dioscorea esculenta) and purple sweet potato flour (Ipomoea batatas L. Poir)

\author{
I Komang Suwita ${ }^{1 *}$, Juin Hadisuyitno ${ }^{1)}$ \\ ${ }^{1)}$ Jurusan Gizi Poltekkes Kemenkes Malang \\ *Email korespondensi: ksuwita@gmail.com
}

Informasi artikel:

Dikirim: 17/08/2020; diterima: 21/12/2020; diterbitkan: 30/03/2021

\begin{abstract}
Background: The development of ice cream products by adding certain ingredients such as fiber can improve the quality of the product as a healthy food. Research purposes: This study aims to analyze the effect of the water-soluble polysaccharide substitution of gembili tubers with purple sweet potato flour on nutritional quality, physicochemical properties, and organoleptic quality of ice cream. Method: This study used a completely randomized design (CRD), consists of four levels, namely control (PO) and water-soluble polysaccharide substitution treatment of gembili tubers with purple sweet potato flour; P1, P2, P3 with three replications each. Results and Discussion: The results of the research on ice cream substitution of water-soluble polysaccharide of gembili tubers with purple sweet potato flour showed a significant effect $(P<0.05)$ on ash, protein, and carbohydrate content, and there was no significant effect on moisture content and energy value. Caused increase in the volume of ice cream products at all levels of substitution treatment (P0, P1, P2, and P3). PO was the ice cream product with the highest increase (2,057 times, and then P3 (1,933 times). In the treatment of ice cream, water-soluble polysaccharide substitution of gembili tubers with purple sweet potato flour, there was a change in the ash, protein, fat, carbohydrate content. energy and increased fiber content. Conclusion: The best level of treatment based on the effectiveness index is P3.
\end{abstract}

Keywords: Water-soluble polysaccharides, purple sweet potato flour, ice cream, nutritional quality, organoleptic quality

\begin{abstract}
ABSTRAK
Latar Belakang: Pengembangan produk es krim dengan menambahkan bahan-bahan tertentu seperti serat dapat meningkatkan kualitas produk sebagai makanan kesehatan. Tujuan: Penelitian ini bertujuan untuk mendapatkan es krim terbaik hasil subtitusi polisakarida larut air umbi gembili dengan tepung ubi jalar ungu terhadap mutu gizi, sifat fisiko-kimia dan mutu organoleptik. Metode: Penelitian ini menggunakan Rancangan Acak Lengkap (RAL), terdiri dari empat taraf, yaitu kontrol (P0) dan perlakuan substitusi polisakarida larut air umbi gembili dengan tepung ubi jalar ungu; $\mathrm{P}_{1}, \mathrm{P}_{2}, \mathrm{P}_{3}$ dengan masing-masing tiga replikasi. Hasil dan Pembahasan: Hasil penelitian es krim subtitusi polisakarida larut air umbi gembili dengan tepung ubi jalar ungu
\end{abstract}


menunjukkan adanya pengaruh yang signifikan $(\mathrm{P}<0,05)$ terhadap kadar abu, protein dan karbohidrat, dan terdapat pengaruh yang tidak singnifikan pada kadar air dan nilai energi. Terjadi peningkatan pengembangan volume produk es krim pada semua taraf perlakuan substitusi (P0, P1, P2 dan P3). P0 merupakan produk es krim yang mengalami peningkatan tertinggi (2,057 kali, dan selanjutnya P3 (1,933 kali). Pada tarap perlakuan es krim subtitusi polisakarida larut air umbi gembili dengan tepung ubi jalar ungu, terjadi perubahan pada kadar abu, protein, lemak, karbohidrat, energi dan peningkatan kadar serat. Kesimpulan: Taraf perlakuan terbaik berdasarkan indeks efektivitas adalah P3.

Kata kunci: polisakarida larut air, tepung ubi jalar ungu, es krim, mutu gizi, mutu organoleptik

\section{PENDAHULUAN}

Konsumsi makanan fungsional meningkat pesat di seluruh dunia terutama karena kesadaran konsumen akan pentingnya diet dalam menjaga kesehatan. Hal ini menyebabkan industri makanan menghabiskan waktu untuk mengembangkan produk alternatif dengan komposisi yang dimodifikasi, yaitu menghilangkan atau membatasi keberadaan beberapa senyawa yang membahayakan kesehatan (Crizel et al., 2014). Pengembangan pangan ini menjadi tantangan karena harus memenuhi permintaan konsumen akan produk yang enak dan sehat serta memiliki karakteristik yang mirip dengan pangan konvensional (Cruz et al., 2009).

Es krim merupakan makanan semi padat yang dibuat dengan cara pembekuan tepung es krim atau campuran susu, lemak hewani maupun nabati, gula, dan dengan atau tanpa bahan makanan lain yang diizinkan sesuai dengan Standar Nasional Indonesia,(1995). Es krim adalah produk susu beku yang lezat dan bergizi yang banyak dikonsumsi di berbagai belahan dunia. Kandungan gizinya ditentukan oleh bahan baku yang digunakan. Kandungan gula yang tinggi $(20,7 / 100 \mathrm{~g})$ dan lemak $(16,0)$ yang sangat tinggi bisa menyebabkan masalah kesehatan di masyarakat (Ayla, 2020).

Akhir-akhir ini, meningkatnya permintaan konsumen akan makanan fungsional yang lebih sehat mendorong produksi es krim mengandung bahan-bahan khusus dengan kandungan gizi tertentu. (Aboulfazli et $a l .$, 2016). Pembuatan es krim menggunakan turunan singkong berupa maltodekstrin dan sumber serat merupakan cara yang efektif untuk meningkatkan kualitas produk (Daiana, 2017).

Pengembangan produk es krim dengan menambahkan bahan-bahan pangan dan zat gizi dapat meningkatkan kualitas produk sebagai makanan kesehatan. Bahan baku utama yang diperlukan pembuatan es krim adalah lemak, bahan kering tanpa lemak (BKTL), bahan pemanis, bahan penstabil, dan bahan pengemulsi (Sari, 2017).

Hasil penelitian pengembangan produk es krim substitusi dengan bahan susu sapi, susu kedelai dan ubi jalar ungu menunjukkan tingkat kesukaan yang baik pada formula tertentu dan juga mempunyai sifat fungsionalnya juga lebih baik karena aktivitas antioksidannya lebih tinggi (Dian, 2011).

Gembili (Dioscorea esculenta) merupakan salah satu spesies tanaman yang mempunyai umbi dan secara botani termasuk dalam genus Dioscorea atau uwi-uwian. Umbi gembili mengandung lendir yang kental dengan komposisi larutan glycoprotein, serat pangan dan diosgenin (Ohizumi et al., 2009). Di Indonesia, tanaman gembili cukup dikenal dan dikembangkan serta dapat ditemukan di beberapa daerah, di antaranya di daerah Banyumas Jawa Tengah (Forum Banyumas, 2012). Panneerselvam dan Jaleel (2008) menyatakan bahwa gembili (Dioscorea esculenta) merupakan sumber zat gizi yang berharga karena mengandung karbohidrat, serat dan rendah lemak, sehingga gembili menjadi sumber makanan yang baik. 
Kandungan gizi umbi gembili memiliki susunan yang bervariasi sesuai dengan spesies dan varietasnya, sebesar 22,5-31,3\% adalah karbohidrat (Sabda 2019), total serat, amilosa, kalium cukup tinggi dan kadar kalium yang rendah memungkinkan dapat digunakan pencegahan dan penanganan penyakit kronis (diabetes mellitus). Pemanfaatan yang lainnya dapat digunakan untuk terapi diet yang memerlukan serat tinggi dan mineral. (Wireko, 2013). Kadar protein tinggi dengan viskositas rendah yang dimiliki umbi gembili baik dikembangkan sebagai tepung komposit untuk produk pangan (Richana dan Sunarti 2004).

Peluang pengolahan umbi gembili di antaranya memanfaatkan sumber bioaktif berupa polisakarida larut air (PLA). PLA pada umbi gembili memiliki sifat fungsional mencakup efek hipoglisemik untuk penderita diabetes (Prabowo et al., 2014).

Menurut Harijono et al. (2012), PLA umbi gembili yang diekstrak dengan berbagai metode ekstraksi yang diberikan pada beberapa kelompok tikus, secara statistik menunjukkan pengaruh yang signifikan terhadap penurunan penyerapan glukosa ke dalam darah tikus.

Ubi jalar ungu sangat potensial dikembangkan sebagai bahan pangan karena kandungan nutrisinya yang tinggi dan bahannya mudah diolah serta banyak tersedia. Dewasa ini ubi jalar ungu telah dimanfaatkan sebagai tepung yang menjadi produk antara atau bahan baku produk olahan. Tepung ubi jalar ungu ini dapat digunakan untuk bahan pembuatan kue, cake, roti, dan produk kue lainnya (Firgianti

dan Sunyoto, 2018). Zat gizi lain yang banyak terdapat dalam ubi jalar adalah vitamin C, vitamin B6 (piridoksin) yang berperan penting dalam kekebalan tubuh. Kandungan mineralnya dalam ubi jalar seperti fosfor, kalsium, mangan, zat besi dan serat yang larut untuk menyerap kelebihan lemak/kolesterol dalam darah (Reifa, 2005).

Ubi jalar ungu mengandung tinggi serat, karbohidrat dengan glikemik rendah serta zat antosianin yang cukup tinggi sebagai antioksidan yang dapat mengurangi re- siko diabetes melitus. Diketahui bahwa diet antioksidan, termasuk antosianin, melindungi sel $\beta$-pankreas dari stres oksidatif glucose induced (Anjani et al., 2018). Ubi jalar ungu mengandung antosianin berkisar \pm 519 $\mathrm{mg} / 100$ gr berat basah (Kumalaningsih, 2006). Antosianin ubi jalar ungu juga memiliki fungsi fisiologis misal antioksidan, antikanker, antibakteri, perlindungan terhadap kerusakan hati, penyakit jantung dan stroke. Ferlina (2010) dalam Sompotan et al., (2019) menyatakan bahwa ubi jalar ungu bisa menjadi anti kanker karena di dalamnya ada zat aktif yang dinamakan selenium dan iodin yang aktivitasnya dua puluh kali lebih tinggi dari jenis ubi yang lainnya.

Penelitian ini bertujuan untuk menentukan es krim substitusi PLA umbi gembili dan tepung ubi jalar ungu terbaik ditinjau dari mutu organolieptik (warna, rasa, tekstur), mutu kimia, mutu gizi.

\section{METODE}

\section{Rancangan Penelitian}

Penelitian ini merupakan penelitian eksperimen. Dengan desain penelitian Rancangan Acak Lengkap (RAL). Terdiri dari 4 taraf perlakuan $(\mathrm{P}) ; 1$ taraf perlakuan kontrol dan 3 taraf perlakuan substitusi PLA umbi gembili dengan tepung ubi jalar ungu. Perbandingan penggunaan PLA umbi gembili dan tepung ubi jalar ungu dalam gram bahan.(gram : gram), yaitu; P0 (0:0), P1 (37,5: 12,5), P2 (25:25), dan P3 (12,5: 37,5). Setiap taraf perlakuan dilakukan replikasi sebanyak 3 kali.

\section{Bahan}

Bahan yang digunakan dalam penelitian ini adalah umbi gembili siap panen yang didapat dari petani di daerah Buring kota Malang, etanol 96\% dan air. Bahan yang digunakan untuk pembuatan es krim meliputi; susu bubuk full cream, PLA umbi gembili, tepung ubi jalar ungu, telur ayam, gula/tropicana slim (gula DM). Bahan kimia untuk analisis mutu gizi dan mutu kimia adalah tablet kjeldhal, $\mathrm{H}_{2} \mathrm{SO}_{4}$ pekat, indikator pp, $\mathrm{NaOH}$ thio $60 \%$, asam borak $4 \%$ yang telah diberi indikator MR-BCG, $\mathrm{HCl} 0,02 \mathrm{~N}$, 
khloroform, $\mathrm{HCl}$ dichromate oxide, aquades. Bahan untuk uji organoleptik adalah sampel es krim kontrol dan es krim subtitusi (es krim perlakuan), serta air putih (aqua).

Alat

Alat yang digunakan untuk pembuatan ekstrak PLA umbi gembili meliputi sentrifuge, tabung sentrifuge, gelas piala, saringan dan oven pengering. Alat untuk pembuatan es krim meliputi waskom, mixer, ice cream maker, panci. Alat untuk analisis mutu gizi dan mutu kimia meliputi oven, tanur, soxhlet aparatus, kjeldal aparatus, timbangan analitik dan peralatan gelas lainnya.

\section{Tahapan penelitian}

Penelitian ini diawali dengan persiapan pembuatan PLA umbi gembili, dan tepung ubi jalar ungu serta mendesain formulasi untuk es krim perlakuan substitusi. Selanjutnya pengolahan es krim kontrol dan es krim perlakuan substitusi.

\section{Metode analisis}

Analisis kadar air, kadar abu, kadar protein, kadar lemak (AOAC. 2005), kadar karbohidrat (by difference), nilai energi menggunakan metode at-water, serat (secara empiris). Uji organoleptik dilakukan dengan metode Hedonic Scale (Soekarto, 1990) menggunakan panelis 25 orang dengan skala tingkat kesukaan (1) Sangat tidak suka, (2) Tidak suka, (3) Suka, dan (4) Sangat suka untuk variabel Warna, Aroma, Tekstur dan Rasa. Pemilihan perlakuan terbaik ditentukan dengan menghitung Indeks Efektifitas (Susrini, 2005) meliputi mutu gizi, mutu kimia dan mutu organolieptik.

\section{Analisis data}

Pengolahan data dilakukan dengan analisis statistik One-Way ANOVA pada tingkat kepercayaan 95\% (Steel \& Torrie, 1993) Apabila hasil analisis menunjukkan pengaruh yang signifikan maka untuk mengetahui pasangan-pasangan taraf perlakuan yang berbeda dilanjutkan dengan analisis Duncan Mutiple Range Test .

Pengolahan data untuk menentukan tingkat penerimaan konsumen dilakukan analisis mutu organoleptik (Soekarto, 1990).
Selanjutnya dianalisis dengan statistik Kruskal-Wallis dan Mann Withnney untuk mengetahui pasangan taraf perlakuan yang menunjukkan perbedaan pengaruh.

\section{HASIL DAN PEMBAHASAN}

\section{Karakteristik es krim kontrol dan es sub- stitusi}

Produk es krim substitusi yang dihasilkan pada penelitian ini adalah es krim kontrol (P0) dan es krim perlakuan (P1, P2 dan P3). Es krim P0 memiliki warna yang lebih putih kekuningan karena terbuat dari bahan susu bubuk full cream dan kuning telur ayam. Sedangkan pada es krim P1, P2 dan P3, semakin banyak proporsi tepung ubi jalar ungu yang digunakan, memberikan warna es krim yang semakin ungu kecokelatan, dikarenakan warna tepung ubi jalar ungu yang digunakan berwarna ungu kecokelatan.

Es krim P0 memiliki aroma yang berbeda dengan es krim substitusi P1 ,P2 dan P3. Es krim P1 menujukan aroma yang lebih khas pada aroma bahan dasarnya yaitu aroma susu full cream, sedangkan es krim substitusi P1, P2 dan P3, menghasilkan aroma yang sudah berbeda yaitu aroma susu full creamnya berkurang.

Untuk rasa es krim ada sedikit perbedaan, yaitu es krim P1 rasa susu terasa kuat, sedangkan es krim substitusi P1, P2 dan P3 rasa susu sudah berkurang karena penambahan PLA umbi gembili dan tepung ubi jalar ungu yang secara mendasar memiliki rasa yang khas yang juga dapat mempengaruhi rasa es krim menjadi berbeda.

Dari segi tekstur, es krim kontrol memiliki tekstur yang lebih kasar dan lebih cepat mencair dibandingkan dengan es krim perlakuan. Penambahan PLA umbi gembili dan tepung ubi jalar ungu pada es krim perlakuan substitusi, yang sifatnya dapat meningkatkan adonan menjadi lebih stabil karena mengandung pati, yang menjadikan es krim lebih lembut dan mencairnya menjadi lebih lambat. Semakin besar proporsi tepung ubi jalar ungu dan semakin sedikitnya PLA umbi gembili yang digunakan, maka semakin lama es krim mencair. 
Es krim mempunyai kemampuan mengembang sesuai dengan bahan yang digunakan. Umumnya semakin tinggi kandungan protein bahan yang digunakan maka semakin besar pengembangan pada produk akhir. Rasio peningkatan berat dari bahan menjadi es krim ditampilkan pada Tabel 1.

Tabel 1. Rasio peningkatan es krim

\begin{tabular}{cccc}
\hline $\begin{array}{c}\text { Taraf perlakuan } \\
\text { (PLA : tepung. ubi } \\
\text { jalar ungu) + gula pasir } \\
(\mathrm{g})+\text { gula DM }(\mathrm{g})\end{array}$ & $\begin{array}{c}\text { Berat } \\
\text { bahan } \\
(\mathrm{g})\end{array}$ & $\begin{array}{c}\text { Berat } \\
\text { produk } \\
\text { es krim } \\
(\mathrm{g})\end{array}$ & $\begin{array}{c}\text { Rasio pen- } \\
\text { ingkatan } \\
\text { berat (kali) }\end{array}$ \\
\hline P0 $(0: 0)+49,5+0$ & 660.10 & 1358 & 2,057 \\
\hline P1 37,5:12,5)+0+15 & 691.10 & 1296 & 1,875 \\
\hline P2 $(25: 25)+0+15$ & 691.10 & 1276 & 1,846 \\
\hline P3 $(12,5: 37,5)+0+15$ & 691.10 & 1336 & 1,933 \\
\hline
\end{tabular}

Es krim P0 yang merupakan bahan utamanya adalah susu full cream yang tinggi lemak dan protein meningkat beratnya

Tabel 2. Analisis rata-rata mutu kimia, mutu gizi, energi dan serat dalam 100 gram es krim

Taraf perlakuan

\begin{tabular}{cccccccc}
$\begin{array}{c}\text { (PLA : tepung ubi jalar } \\
\text { ungu) + gula pasir }(\mathrm{g})+ \\
\text { gula DM }(\mathrm{g})\end{array}$ & Air $(\%)$ & $\begin{array}{c}\text { Abu } \\
(\%)\end{array}$ & $\begin{array}{c}\text { Protein } \\
(\text { gram })\end{array}$ & $\begin{array}{c}\text { Lemak } \\
(\text { gram })\end{array}$ & $\begin{array}{c}\text { Karbohidrat } \\
(\text { gram })\end{array}$ & $\begin{array}{c}\text { Energi } \\
(\text { Kkal })\end{array}$ & $\begin{array}{c}\text { Serat } \\
(\text { gram })\end{array}$ \\
\hline P0 $(0: 0)+49,5+0$ & $73,786^{\mathrm{a}}$ & $0,033^{\mathrm{a}}$ & $5,9978^{\mathrm{a}}$ & 5,97 & $14,21^{\mathrm{a}}$ & $134,57^{\mathrm{a}}$ & 0,015 \\
\hline $\mathrm{P} 1(37,5: 12,5)+0+15$ & $72,186^{\mathrm{b}}$ & $0,293^{\mathrm{b}}$ & $4,1580^{\mathrm{b}}$ & 6,26 & $17,10^{\mathrm{b}}$ & $141,38^{\mathrm{b}}$ & 0,130 \\
\hline $\mathrm{P} 2(25: 25)+0+15$ & $71,999^{\mathrm{b}}$ & $0,539^{\mathrm{c}}$ & $6,3857^{\mathrm{c}}$ & 6,37 & $14,71^{\mathrm{ac}}$ & $141,70^{\mathrm{b}}$ & 0,220 \\
\hline P3 $(12,5: 37,5)+0+15$ & $72,203^{\mathrm{b}}$ & $0,481^{\mathrm{d}}$ & $5,2934^{\mathrm{d}}$ & 6,10 & $15,92^{\mathrm{c}}$ & $139,77^{\mathrm{ab}}$ & 0,289 \\
\hline
\end{tabular}

Huruf yang berbeda menunjukkan adanya perbedaan yang signifikan $(\alpha=0,05)$

\section{Kadar air}

Hasil analisis kadar air es krim substitusi berkisar antara 71,999 - 73,786\% (Tabel 2). Uji statistik terhadap kadar air es krim substitusi menunjukkan adanya pengaruh substitusi PLA umbi gembili dengan tepung ubi jalar ungu yang bermakna $(\mathrm{P}<0,05)$. Dan uji lanjut diketahui terdapat perbedaan antara P0 dengan P1, P2 dan P3. P0 memiliki kadar air tertinggi dibandingkan P1, P2 dan P3 karena P0 menggunakan bahan padat yang lebih sedikit berupa susu full cream saja dibandingkan dengan $\mathrm{P} 1, \mathrm{P} 2$ dan P3. Sedangkan P1, P2 dan P3 menggunakan bahan padat yang lebih banyak, sehingga meningkatkan viskositas pada adonan es krim. Tingginya kadar air es krim ini karena memang bahan es krim berupa adonan cair yang dibekukan. Kadar air es krim substitusi ini lebih tinggi dari hasil penelitian Pratiwi et al. (2016), yaitu es krim dengan bahan formulasi gel buah okra,
(2,057 kali). Sedangkan es krim substitusi P3 (1,933 kali) peningkatan berat dibandingkan dengan es krim substitusi P1 $(1,875)$ dan P2 $(1,846)$. Es krim P3 lebih banyak menggunakan tepung ubi jalar ungu yang mempunyai kandungan protein lebih tinggi dibandingkan P1 dan P2.

\section{Komposisi kimia dan mutu gizi es krim substitusi}

Mutu gizi es krim meliputi protein, lemak, karbohidrat, serat dan energi, sedangkan mutu kimia yaitu kadar air dan kadar abu. Beberapa penilaian es krim mengacu pada SNI No. 01-3713-1995. susu sapi dan susu kedelai, dengan kisaran kadar air antara 63,24-64,88\%, dan es krim yang berbahan bubuk mandai cempedak mempunyai kadar airnya sebesar $62,25 \pm 0,07 \%$ (Rahmadi et al. (2018). Sedangkan penelitian Prasetyani et al. (2020) yang menggunakan bahan sari kedelai, tepung ampas kelapa dan bunga telang, menunjukkan kadar air lebih tinggi antara 76,24-78,17\%.

Perbedaan kadar air dari beberapa produk es krim, dapat disebabkan karena penggunaan bahan baku yang ditambahkan berbeda-beda. Jenis bahan pangan memiliki karakteristik yang berbeda dan juga memiliki kemampuan mengikat air berbedabeda sehingga berpengaruh terhadap kandungan kadar air produk akhir.

\section{Kadar abu}

Rata-rata kadar abu es krim substitusi terdapat pada Tabel 2, yaitu antara 0,033- 
0,539\%. Kadar abu pada es krim menunjukkan nilai yang berbeda antara $\mathrm{P} 0$, P1, P2 dan P3. Dan uji statistik terhadap kadar abu es krim menunjukkan adanya pengaruh substitusi PLA umbi gembili dengan tepung ubi jalar ungu yang bermakna $(\mathrm{P}<0,05)$, dan hasil uji lanjut ditemukan adanya perbedaan yang bermakna antara taraf perlakuan. Kadar abu pada es krim substitusi lebih rendah jika dibandingkan dengan kadar abu es krim menurut Pratiwi et al. (2016), dengan bahan formulasi gel buah okra, susu sapi dan susu kedelai, antara $1,08-1,64 \%$. Demikian juga es krim menurut Prasetyani et al. (2020), dengan bahan sari kedelai, tepung ampas kelapa dan bunga telang, memiliki kadar abu yaitu antara $0,68-0,76 \%$. Penelitian lain menunjukkan kadar abu es krim dengan bahan kefir puree buah naga merah, yaitu rata-rata perlakuan T0 $(0,82 \pm 0,14 \%)$ dan T3 $(0,74 \pm 0,00 \%)$ (Khasanah et al., 2020).

Tinggi rendahnya kadar abu pada bahan pangan, tergantung dari jenis bahan pangan tersebut. Semakin tinggi kandungan mineral dari bahan pangan, maka kadar abunya semakin tinggi.

\section{Kadar protein}

Rata-rata kadar protein es krim substitusi tercantum pada Tabel 2, yaitu berkisar antara 4,158-6,3857\%). Kadar protein es krim tersebut berada di atas syarat es krim menurut SNI No 01-3713-1995, yaitu minimal $2,7 \%$, dan menurut Astawan (2011), sebesar $4 \%$. Kadar protein pada es krim menunjukkan adanya perbedaan nilai antara P0, P1, P2 dan P3.

Hasil uji statistik terhadap kadar protein es krim menunjukkan adanya pengaruh yang bermakna $(\mathrm{P}<0,05)$, dan hasil uji lanjut diketahui adanya perbedaan yang bermakna

di antara taraf perlakuan. Beberapa hasil pengembangan produk es krim yang diformulasi dengan bahan-bahan yang berbeda, yang menunjukkan kadar protein yang tidak jauh berbeda, seperti produk es krim yang berbahan tambahan jagung manis dan rumput laut (Satriani et al., 2018) menunjukkan kadar protein berkisar antara
3,02-3,72\%, dan es krim yang berbahan pasta uwi ungu (Awaliah et al., 2018) dengan kadar protein 3,79\%.

Protein yang terdapat dalam bahan adonan es krim berfungsi untuk membantu pembuihan karena protein susu akan teradsorpsi dalam lapisan film pada permukaan sehingga mengikat udara ke dalam adonan melalui pembentukan buih ketika dilakukan pengadukan, menstabilkan emulsi lemak setelah proses homogenisasi, menambah cita rasa, meningkatkan dan menstabilkan daya ikat air yang berpengaruh pada kekentalan dan tekstur es krim, juga dapat meningkatkan nilai overrun es krim. Kandungan protein yang tidak jauh berbeda dari beberapa produk pengembangan es krim ini dikarenakan menggunakan bahan tambahan yang mengandung nilai protein rendah.

\section{Kadar lemak}

Kadar lemak es krim substitusi pada ditunjukkan pada Tabel 2, berkisar antara 5,97-6,37\%. Kadar lemak tersebut jauh di bawah kadar lemak es krim menurut (Padaga dan Sawitri, 2005) yaitu antara 8-16\% dan Astawan, (2011) sebesar 12,5\%, namun mendekati syarat es krim menurut SNI No 01-3713-1995, yaitu minimal 5,0\%.

Kadar lemak es krim substitusi menunjukkan angka yang berbeda, hal itu disebabkan karena perbedaan proporsi bahan baku yang digunakan.

Kadar lemak es krim substitusi ini berada di bawah kadar lemak es krim berbahan jagung (Moulina, 2016), yaitu ratarata $10,19 \%$, dan di atas kadar lemak es krim $(2,13 \%)$ yang menggunakan tambahan bahan jagung manis dan rumput laut (Sattriani et al,. 2018), dan es krim dengan bahan tambahan pasta uwi ungu yaitu rata-rata 2,4\% (Awaliah et al., 2018). Perbedaan kadar lemak dari beberapa produk es krim tersebut dikarenakan menggunakan bahan yang ditambahkan dari jenis yang berbeda yang memiliki kandungan lemak juga berbeda-beda. 


\section{Kadar karbohidrat}

Kadar karbohidrat es krim substitusi pada Tabel 2 berkisar antara 14,21-17,10\%. Berbeda dengan produk padat lainnya yang mengandung karbohidrat lebih tinggi, karena es krim walaupun bentuknya padat akan tetapi merupakan bahan cair yang dipadatkan melalui pembekuan. Produk es krim dengan kadar air yang tinggi memiliki padatan yang rendah sehingga kadar karbohidratnya juga rendah.

Hasil uji statistik terhadap kadar karbohidrat es krim substitusi menunjukkan adanya pengaruh yang bermakna $(\mathrm{P}<0,05)$, dan hasil uji lanjut diketahui adanya perbedaan yang bermakna antara $\mathrm{P} 0$ dengan P1 dan P3, dan P1 dengan P3. Beberapa produk pengembangan es krim dengan kandungan karbohidratnya yang lebih tinggi dari produk es krim substitusi ini, seperti es krim dengan penambahan jagung manis dan rumput laut (Satriani et al., 2018), yaitu ratarata 28,87-36,09\%, penelitian Rahmadi et al., (2018) es krim berbahan puree dan bubuk mandai cempedak memiliki kisaran karbohidrat antara 26,35-36,12\%, dan juga penelitian Khasanah et al. (2020), es krim kefir puree buah naga merah memiliki kadar karbohidrat antara 28,12-32,86\%. Sedangkan es krim sari kedelai dan tepung ampas kelapa dengan pewarna telang, hasil penelitian Prasetyani et al. (2020), memiliki kadar karbohidrat yang tidak jauh berbeda dengan es krim substitusi ini, yaitu berkisar antara $12,64-18,03 \%$.

Adapun yang menyebabkan kadar karbohidrat berbeda antara produk es krim tersebut, karena setiap produk es krim menggunakan jenis bahan tambahan yang berbeda, yang mana bahan-bahan tersebut memiliki kandungan karbohidrat yang jumlahnya juga berbeda.

\section{Nilai energi}

Berdasarkan data hasil analisis kadar protein, karbohidrat dan lemak, yang selanjutnya dihitung menggunakan metode at-water, maka diperoleh nilai energi es krim substitusi pada Tabel 2, yaitu berkisar 134,57 - 141,70 kkal. Hasil uji statistik nilai energi es krim substitusi menunjukkan adanya pengaruh $(\mathrm{P}<0,05)$, dan hasil uji lanjut diketahui adanya perbedaan yang bermakna antara P0 dengan P1 dan P2. Terjadinya perbedaan nilai energi es krim substitusi P0 dengan P1 dan P2 dikarenakan penambahan PLA umbi gembili dan tepung ubi jalar ungu. Sedangkan pada P3 terjadi peningkatan bobot produk es krim lebih besar yang menjadikan persentase nilai energi pada es krim kecil.

Nilai energi yang dihasilkan es krim substitusi ini lebih rendah dari es krim kefir puree buah naga merah hasil penelitian Khasanah et al,. (2020) yang berkisar 185,86-218,97 kkal. Nilai energi yang dihasilkan dari masing-masing produk es krim tergantung dari jenis bahan yang digunakan, terutama bahan makanan sumber karbohidrat, lemak dan protein, semakin banyak penambahan bahan sumber tersebut maka menghasilkan produk dengan energi yang semakin tinggi.

\section{Kadar serat kasar}

Hasil analisis kadar serat kasar es krim substitusi pada Tabel 2, yaitu antara 0,015 $0,289 \%$. Es krim P0 memiliki kadar serat terendah $(0,015 \%)$ dibanding dengan es krim substitusi P1, P2 dan P3. Meningkatnya kadar serat pada es krim subtitusi dikarenakan penambahan PLA dan tepung ubi jalar ungu, yang mana dalam setiap 100 gram tepung ubi jalar ungu mengandung 4,72 gram serat kasar (Ambarsari et al., 2009).

Kadar serat kasar es krim substitusi (Tabel 2) sedikit lebih rendah dibanding dengan kadar serat es krim penambahan gel buah okra (Pratiwi et al., 2016), yaitu 0,38$0,78 \%$, dan jauh lebih rendah dari serat es krim dengan penambahan puree umbi ganyong (Prahesti, 2019), yaitu 6,01\%, serta mendekati serat es krim dengan bahan sari kedelai dan tepung ampas kelapa dan bunga telang (Prasetyani et al., 2020), yaitu antara 0,08-0,18\%. Kadar serat pada es krim dipengaruhi oleh jenis bahan yang digunakan dan jenis serat (larut dan tidak 
larut) yang terdapat di dalam bahan pangan tersebut.

Rendahnya kadar serat kasar es krim substitusi dikarenakan bahan yang ditambahkan berupa PLA yang mengandung serat pangan larut air dan tepung ubi jalar ungu yang juga mengandung serat pangan larut dan tidak larut air.

\section{Mutu organoleptik es krim substitusi}

Menurut Moehyi (1992) bahwa dalam menilai mutu organoleptik suatu produk makanan diperlukan adanya atribut penilaian. Dan menurut Sukarto (1990), secara umum mutu fisik merupakan sifat yang terdapat di dalam bahan dan produk pangan seperti warna, aroma, rasa dan tekstur.

Tabel 3. Tingkat penerimaan panelis dan modus tingkat kesukaan terhadap warna, aroma, rasa dan tekstur es krim

\begin{tabular}{ccccccccc}
\hline \multirow{2}{*}{$\begin{array}{c}\text { Taraf perlakuan } \\
\text { (PLA : tepung ubi jalar ungu) } \\
\text { + gula pasir }(\mathrm{g})+\text { gula DM }(\mathrm{g})\end{array}$} & \multicolumn{2}{c}{ Warna } & \multicolumn{2}{c}{ Aroma } & \multicolumn{2}{c}{ Rasa } & \multicolumn{2}{c}{ Tekstur } \\
\cline { 2 - 10 } & $\begin{array}{c}\text { Rata- } \\
\text { rata }\end{array}$ & Modus & $\begin{array}{c}\text { Rata- } \\
\text { rata }\end{array}$ & Modus & $\begin{array}{c}\text { Rata- } \\
\text { rata }\end{array}$ & Modus & $\begin{array}{c}\text { Rata- } \\
\text { rata }\end{array}$ & Modus \\
\hline P0 $(0: 0)+49,5+0$ & 3,60 & $4^{\text {a }}$ & 3,76 & $4^{\text {a }}$ & 3,32 & $4^{\text {a }}$ & 2,92 & $3^{\text {a }}$ \\
\hline P1 $(37,5: 12,5)+0+15$ & 2,96 & $3^{\text {ab }}$ & 3,24 & $3^{\text {b }}$ & 2,88 & $3^{\text {a }}$ & 2,84 & $3^{\text {a }}$ \\
\hline P2 $(25: 25)+0+15$ & 2,92 & $3^{\text {c }}$ & 3,24 & $3^{\text {c }}$ & 3,04 & $3^{\text {a }}$ & 2,84 & $3^{\text {a }}$ \\
\hline P3 $(12,5: 37,5)+0+15$ & 2,92 & $3^{\text {ab }}$ & 3,04 & $3^{\text {ab }}$ & 3,16 & $3^{\text {a }}$ & 3,00 & $3^{\text {a }}$ \\
\hline
\end{tabular}

Keterangan: Huruf yang berbeda menunjukkan adanya perbedaan yang signifikan $(\alpha=0,05)$

Warna

Warna merupakan salah satu parameter yang penting dalam penilaian suatu produk pangan. Menurut Winarno (2004), warna salah satu atribut yang ikut menentukan mutu. Dijelaskan juga bahwa dalam menghasilkan produk pangan, warna akan menentukan daya terima produk tersebut pada konsumen. Produk pangan akan dapat diterima dengan baik oleh konsumen jika warna produk pangan itu menarik. Hasil uji penerimaan terhadap warna es krim pada Tabel 3 menunjukkan rata-rata 2,92 - 3,6 dengan nilai modus 3 dan 4. Pada es krim P0 memperoleh tingkat penerimaan tertinggi yaitu sangat suka, dan pada es krim P1, P2 dan P3 terjadi penurunan tingkat penerimaan yaitu dengan tingkat penerimaan kategori suka. Sehingga dapat disimpulkan tingkat penerimaan es krim substitusi terhadap warna menunjukkan produk ini dapat diterima dengan baik oleh panelis.

Hasil analisis uji statistik menunjukkan bahwa es krim substitusi berpengaruh nyata $(\mathrm{p}<0,05)$ terhadap warna produk es krim yang dihasilkan, dan hasil uji lanjut es krim P0 berbeda nyata dengan P2, dan P2 berbeda nyata dengan P1 dan P3. Sedangkan antara P0 dengan P1 dan P3 menunjukkan tidak ada perbedaan nyata. Perbedaan warna terjadi pada es krim P0 dengan P2 dan P2 dengan P1 dan P3 dikarenakan penggunaan bahan baku berupa tepung ubi jalar ungu yang berwarna ungu kecokelatan dengan proporsi yang berbeda memberikan warna produk akhir es krim yang berbeda. Ubi jalar ungu mengandung tinggi antosianin. Antosianin memiliki kecenderungan terpolimerisasi pada kondisi oksidatif seperti adanya paparan oksigen, cahaya, dan panas yang menyebabkan perubahan warna menjadi cokelat, atau biasa disebut browning. Herlina et al. (2018) menyatakan bahwa variasi perlakuan penambahan tepung glukomanan dari umbi gembili berpengaruh nyata $(p<0,05)$ terhadap warna es krim.

\section{Aroma}

Tingkat penerimaan panelis terhadap aroma es krim pada Tabel 3 berkisar 3,04 3,76 dengan nilai modus 3 dan 4 . Penerimaan panelis terhadap produk es krim P0 adalah sangat disukai, sedangkan es krim substitusi P1, P2 dan P3 adalah produk es krim yang disukai. Dapat disimpulkan, bahwa es krim substitusi ini dapat diterima dengan kategori "suka".

Hasil analisis uji statistik menunjukkan bahwa es krim substitusi berpengaruh nyata $(\mathrm{p}<0,05)$ terhadap aroma produk es krim yang dihasilkan, dan hasil uji lanjut es krim 
$\mathrm{P} 0$ berbeda nyata dengan $\mathrm{P} 1$ dan $\mathrm{P} 2$, dan $\mathrm{P} 1$ berbeda nyata dengan $\mathrm{P} 2$, dan $\mathrm{P} 2$ berbeda nyata dengan P3. Sedangkan antara P0 dengan P3 menunjukkan tidak ada perbedaan yang nyata. Perbedaan aroma terjadi pada es krim P0 dengan P1 dan P2, dan $\mathrm{P} 2$ dengan $\mathrm{P} 3$, dikarenakan penggunaan bahan baku berupa tepung ubi jalar ungu yang memiliki aroma khas tepung ubi jalar ungu dan dengan penggunaan proporsi yang berbeda sehingga memberikan aroma produk akhir es krim yang berbeda pula.

\section{Rasa}

Rasa dari suatu produk makanan adalah merupakan salah satu faktor yang menentukan daya terima dari konsumen. Rasa suatu produk dipengaruhi oleh beberapa faktor, di antaranya senyawa kimia, suhu, konsentrasi dan interaksi dengan komponen rasa yang lain. Tingkat penerimaan panelis terhadap rasa pada es krim rata-rata berkisar 2,88 - 3,32 dengan nilai modus 3 dan 4 . Tingkat kesukaan es krim P0 adalah kategori sangat suka, dan tingkat penerimaan P1, P2 dan P3 yaitu kategori suka. Dengan demikian produk es krim substitusi ini dapat diterima dengan baik.

Hasil analisis uji statistik es krim substitusi menunjukkan tidak ada perbedaan yang signifikan $(p>0,05)$ terhadap rasa produk es krim yang dihasilkan. Tidak adanya perbedaan secara statistik penerimaan terhadap rasa dari masingmasing perlakuan es krim substitusi disebabkan penambahan bahan tidak merubah penilaian panelis.

\section{Tekstur}

Tekstur merupakan salah satu parameter mutu organoleptik penting pada suatu produk. Penggunaan telur pada pembuatan es krim dapat berpengaruh terhadap tekstur dan juga dapat menjaga kestabilan adonan. Senyawa yang bertindak sebagai emulsi pada telur adalah lecitin dan chepalin yang merupakan komponen lemak telur. Fungsi lain pada telur adalah sebagai pengaerasi, pelembut, dan pengikat. Albumen (putih telur) membantu dalam pembentukan struktur adonan karena kemampuannya menangkap udara pada saat adonan dikocok dan memberikan kontribusi udara dalam adonan. Selain itu, telur juga dapat menambah gizi, warna, serta menguatkan flavour (Matz SA \& T. D. Matz, 1978). Albumen adalah protein yang bersifat sebagai emulsifier dengan kekuatan biasa, sedangkan kuning telur merupakan emulsifier yang kuat. Paling sedikit sepertiga kuning telur terdiri dari lemak akan tetapi kandungan lesitin yang menyebabkan kuatnya daya emulsifier (Winarno, 2004).

Tingkat penerimaan panelis terhadap tekstur es krim pada Tabel 3 berkisar 2,84 3,00 , dengan nilai modus 3. Tingkat kesukaan panelis terhadap tekstur es krim (P0, P1, P2 dan P3) adalah rata-rata 3 (suka). Hasil analisis uji statistik menunjukkan tidak ada perbedaan $(\mathrm{p}=0,746)$ terhadap tekstur produk es krim yang dihasilkan. Tidak adanya perbedaan secara statistik penerimaan terhadap tekstur dari masingmasing perlakuan es krim substitusi disebabkan penambahan bahan tidak merubah penilaian panelis.

\section{Penentuan perlakuan terbaik}

Analisis pemilihan perlakuan terbaik menggunakan modifikasi metode de Garmo dalam Susrini (2005), dilakukan dengan meminta pendapat responden tentang urutan (ranking) pentingnya peranan variabel terhadap mutu produk.

Variabel yang digunakan sebagai dasar penentuan ranking, yaitu mutu gizi, mutu kimia dan mutu organoleptik es krim yang didapat dari penilaian responden. Hal ini menunjukkan bahwa tingkat penerimaan konsumen terhadap produk es krim substitusi sudah baik, sehingga penilaian panelis merupakan faktor utama dalam menentukan suatu produk yang disukai. Berdasarkan hasil penentuan taraf perlakuan, didapatkan P3 merupakan produk perlakuan es krim yang terbaik. Formulasi P3 terdiri dari PLA : tepung ubi jalar ungu $(12,5 \mathrm{~g}: 37,5 \mathrm{~g})+$ gula pasir $(0 \mathrm{~g})+$ gula DM (15 gram tropicana slim) dengan nilai hasil $(\mathrm{NH}) \quad 0,570$. 


\section{KESIMPULAN}

Es krim substitusi PLA umbi gembili dengan tepung ubi jalar ungu berpengaruh nyata terhadap kadar abu, protein dan karbohidrat, dan terdapat pengaruh yang tidak singnifikan terhadap kadar air dan nilai energi. Uji daya terima (organoleptik) es krim substitusi, diperoleh ada pengaruh yang signifikan terhadap warna dan aroma, dan tidak ada pengaruh terhadap rasa dan tekstur.

Substitusi PLA umbi gembili dengan tepung ubi jalar ungu pada es krim menyebabkan perubahan pada kadar abu, protein, lemak, karbohidrat, energi dan peningkatan kadar serat. Substitusi polisakarida larut air (PLA) umbi gembili dengan tepung ubi jalar ungu pada es krim substitusi menyebabkan penurunan kesukaan terhadap warna dan aroma, peningkatan kesukaan terhadap rasa dan tekstur. Taraf perlakuan terbaik es krim berdasarkan indeks efektivitas adalah P3 dengan formulasi perbandingan PLA : tepung ubi jalar ungu $(12,5: 37,5),+0$ g gula pasir +15 $\mathrm{g}$ tropikana slim (gula DM).

\section{SARAN}

Perlu dilakukan uji lanjut pada produk es krim substitusi polisakarida larut air (PLA) umbi gembili dengan tepung ubi jalar ungu berupa uji indeks glikemik untuk mengetahui respon glukosa darah responden.

\section{DAFTAR PUSTAKA}

Aboulfazli, F., Shori, A. B., \& Baba, A. S. (2016). Effects of the replacement of cow milk with vegetable milk on probiotics and nutritional profile of fermented ice cream. LWT Food Sci Technol, 70, 261-270. https://doi. org/10.1016/j.lwt.2016.02.056

Affandi, D. R., \& Handajani, S. (2011). Es krim ubi jalar ungu (Ipomoea batatas): Tinjauan sifat sensoris, fisik, kimia, dan aktivitas antioksidannya. Jurnal Teknologi Hasil Pertanian, 4(2).
Ambarsari, I., Sarjana, S., \& Choliq, A. (2009). Rekomendasi dalam penetapan standar mutu tepung ubi jalar. Jurnal standardisasi, $\quad 11(3), \quad 212-219$. http://dx.doi.org/10.31153/ js.v11i3.676

Anjani, E.P., Oktarlina, R.Z., \& Morfi, C.W. (2018). Zat antosianin pada ubi jalar ungu terhadap diabetes melitus fakultas kedokteran, universitas lampung. Jurnal Majority, 7(2), 257262. http://juke.kedokteran.unila.ac. $\mathrm{id} /$ index.php/majority/article/view/188 6

AOAC. (2005). Official methods of analysis of the association of official analytical chemist. Washington: AOAC.

Astawan, M. (2011). Kandungan gizi es krim. http://www.loveicecream. 110mb.com

Awalilah, R., Ansharullah, A., \& Mashuni, M. (2018). Pengaruh penambahan pasta uwi ungu (discorea alata L) terhadap kualitas organoleptic dan fisiko kimia es krim. Jurnal Sains dan Teknologi Pangan, 3(1), 1018-1026. http://ojs.uho.ac.id/index.php /jstp/article/viewFile/3974/3051

Ayla, A., Salik, M.A. (2020) Functional ice cream technology akademik gida, 18(2), 180-189. http://doi.org/ 10.24323/akademik-gida.758835

Badan Standarisasi Nasional. (1995). SNI 01-3713-1995: es krim. BSN, Jakarta.

Crizel, T. D. M., Araujo, R. R. D., Rios, A. D. O., Rech, R., \& Flôres, S. H. (2014). Orange fiber as a novel fat replacer in lemon ice cream. Food Science and Technology, 34(2), 332340. https://doi.org/10.1590/fst.2014 .0057

Cruz, A. G., Antunes, A. E., Sousa, A. L. O., Faria, J. A., \& Saad, S. M. (2009). Icecream as a probiotic food carrier. Food Research International, 42(9), 12331239. https://doi.org/10.1016/j.foodres. 2009.03.020

Damardjati, D. S., S. Widowati dan Suismono. (1993). Pembinaan sistem 
agroindustri tepung kasava pola usaha tani plasma di kabupaten ponorogo. Laporan Penelitian Kerjasama Balittan Sukamandi dengan PT. Petro Aneka Usaha. Sukamandi.

de Souza Fernandes, D., Leonel, M., Del Bem, M. S., Mischan, M. M., Garcia, É. L., \& Dos Santos, T. P. R. (2017). Cassava derivatives in ice cream formulations: effects on physicochemical, physical and sensory properties. Journal of food science and technology, 54(6), 1357-1367. https://doi.org/10.1007/s13197-0172533-8

Dufie, W. M. F., Oduro, I., Ellis, W. O., Asiedu, R., \& Maziya-Dixon, B. (2013). Potential health benefits of water yam (Dioscorea alata). Food \& function, 4(10), 1496-1501. https://doi.org/10.1039/C3FO60064E

Firgianti, G., \& Sunyoto, M. (2018, May). Karakterisasi fisik dan kimia ubi jalar ungu (Ipomoea batatas L) varietas biang untuk mendukung penyediaan bahan baku tepung ubi jalar ungu. In Prosiding Seminar Nasional Fakultas Pertanian UNS (Vol. 2, No. 1, pp. F104). https://jurnal.fp.uns.ac.id/index.php/semnas/article/view/1154

Forum Banyumas. (2012). Panen gembili 2012 dengan Bupati Marjoko. http://forumbanyumaskab.blogspot.co $\mathrm{m} / 2012 / 06 /$ panen-gembili-2012dengan-bupati-marjoko.html.

Harijono, Estiasih, T., Sunarharum, W. B,. dan Suwita I. K. (2012). Efek hipoglikemik polisakarida larut air gembili (dioscorea esculenta) yang diekstrak dengan berbagai metode. Jurnal Teknologi dan Industri Pangan,IPB University, 23(1), 1-8. https://jurnal.ipb.ac.id/index.php/jtip/ar ticle/view/5286
Herlina H., Miftahul C., Bambang H. P., Maharlika P. B. N., \& Nita K., (2018). Penggunaan tepung glukomanan dari umbi gembili (dioscorea esculenta L.) pada pembuatan es krim. Jurnal Agritech, 38(4), 404-412. http://doi.org/10.22146/agritech.16907

Khasanah, K., S., Susanti, S., dan Legowo, M., A. (2020). Karakteristik es krim kefir puree buah naga merah sebagai pangan fungsional antiobesitas. Jurnal Teknologi Pangan dan Gizi, 19 (2), 53-62. https://doi.org/10.33508/jtpg. v19i2.2749

Kumalaningsih, Sri. (2006). Antioksidan alami. Surabaya: Trubus Agrisarana

Matz SA \& T. D. Matz. (1978). Cookies and crackers technology. Texas: The AVI Publishing Co., Inc.

Moulina, A., M. (2016). Pemanfaatan jagung (zea mays $L$ ) sebagai bahan pembuatan es krim. Agritepa, 3(1), 32-45. https://doi.org/10.37676/agritepa.v3i2. 532

Ohizumi, Y., Gaidamashvili, M., Ohwada, S., Matsuda, K., Kominami, J., Nakamura-Tsuruta, $\quad$ S., $\quad \ldots \quad$ \& Muramoto, K. (2009). Mannosebinding lectin from yam (Dioscorea batatas) tubers with insecticidal properties against Helicoverpa armigera (Lepidoptera: Noctuidae). Journal of agricultural and food chemistry, 57(7), 2896-2902. https://doi.org/10.1021/jf8040269

Panneerselvam, R., \& Jaleel, C,A. (2008). Starch and sugar conversion in Dioscorea esculenta tubers and Curcuma longa rhizomes during storage. Caspian J. Env. Sci., 6 (2), 151-160. https://www.sid.ir/en/ Journal/ViewPaper.aspx?ID=144330 
Prabowo, A. Y., Estiasih, T., \& Purwantiningrum, I. (2014). Umbi gembili (Dioscorea esculenta L.) sebagai bahan pangan mengandung senyawa bioaktif: kajian pustaka. Jurnal Pangan dan Agroindustri, 2(3), 129-135.

Prahesti, E. (2019). Pengaruh penambahan puree umbi ganyong (canna edulis kerr) terhadap sifat organoleptic es krim. E-Jurnal Tata Boga, 8(3), 417424. https://jurnalmahasiswa. unesa.ac.id/index.php/jurnal-tataboga/article/view/14211

Prasetyani, W., Fadhilla, R., Angkasa, D., Ronitawati, P., \& Melani, V. (2020). Analisis nilai gizi dan daya terima es krim sari kedelai dan tepung ampas kelapa dengan pewarna alami bunga telang sebagai makanan selingan untuk anak usia sekolah. Jurnal Pangan dan Gizi, 10 (02), 12-32. https://doi.org/10. 26714/jpg.10.2.2020.12-32

Pratiwi, I., K., Zaini, A., M., \& Nazaruddin (2016). Pengaruh konsentrasi gel buah okra (abelmoschus esculentus L.) terhadap mutu es krim campuran susu sapid an susu kedelai. ProFood (Jurnal Ilmu dan Teknologi Pangan), 2 (2), 132-139. http://www.profood. unram.ac.id/index.php/profood/article/ view/28

Rahmadi, A., Firdaus, R., A., F., \& Marwati (2018). Karakteristik sifat sensoris, Pproksimat, antioksidan, total BAL, dan uji pasar es krim berbahan puree dan bubuk mandai cempedak. Jurnal Riset Teknologi Industri. 66-76.

Richana, N., \& Sunarti, T.C. (2004) Karakterisasi Sifat Fisikokimia Tepung Umbi dan Tepung Pati Dari Umbi Ganyong, Suweg, Ubi Kelapa, dan Gembili. Jurnal Pascapanen, 1(1), 2937. http://pascapanen.litbang.pertanian. go.id/assets/media/publikasi/jurnal/j.Pa scapanen.2004_1_4.pdf
Sabda, M., Wulanningtyas, HS., Ondikeleuw, M., \& Baliadi, Y., (2019). Karakterisasi potensi gembili (dioscorea esculenta 1.) lokal asal papua sebagai alternatif bahan pangan pokok (characterization of potential local gembili (dioscorea esculenta 1) from papua as alternative of staple food). Bul. Plasma Nutfah, 25(1), 2532. http://dx.doi.org/10.21082/blpn. v25n1.2019.p25-32

Sari, N., Widanti, Y. A., Mustofa, A. (2017) Karakteristik es krim labu kuning (Curcubita moschata) dengan variasi jenis susu. JITIPARI (Jurnal Ilmiah Teknologi dan Industri Pangan UNISRI), 2(2). http://dx.doi.org/ 10.33061/jitipari.v2i2.1895

Satriani, Sukainah, A., Mustari, A. (2018). Analisis fisiko-kimia es krim dengan penambahan jagung manis (Zea Mays L. Saccharata) dan rumput laut (Eucheuma cottonii). Jurnal Pendidikan Teknologi Pertanian, 4, 105-124. https://doi.org/10.26858/jptp .v1i0.6237

Soekarto, S.T. (1990). Penilaian organoleptik untuk industri pangan dan hasil pertanian. Jakarta: Bhatara Aksara.

Sompotan, H. D. N, Mongi, J., Karauwan, F.A., Karundeng, \& E. Z. S. S., (2019). Uji stabilitas sediaan salep ekstrak etanol umbi ubi jalar ungu (Ipomea batatas L.). Jurnal Biofarmasetikal Tropis, 2 (2), 69-74. https://journal. fmipaukit.ac.id/index.php/jbt/article/vi ew/105

Steel, R. G. D., \& Torrie, J. H. (1993). Prinsip dan prosedur statistika (diterjemahkan dari: principles and procedures of statistic, (penerjemah: B. Sumantri). PT Gramedia: Jakarta.

Susrini. (2005). Indeks Efektifitas: Suatu pemikiran tentang alternatif untuk memilih perlakuan terbaik pada penelitian pangan. Program Studi Teknologi Hasil Ternak. Universitas Brawijaya. Malang 
Winarno, F. G. (2004). Kimia pangan dan

gizi. Gramedia Pustaka Utama: Jakarta 